\title{
Investigation of Nitroblue Tetrazolium Reduction of Neutrophils in the Dog Infected with Hepatozoon canis
}

\author{
Tomoaki MURATA, Reiko TAGAMI*, Makoto INOUE**, Yuji UZUKA*, \\ Yasuho TAURA, and Sanenori NAKAMA \\ Departments of Veterinary Surgery, ${ }^{*}$ Veterinary Internal Medicine, and ${ }^{* *}$ Veterinary Pathology, \\ Faculty of Agriculture, Yamaguchi University, 1677-1 Yoshida, Yamaguchi-shi, \\ Yamaguchi 753, Japan
}

(Received 20 April 1993/Accepted 13 July 1993)

\begin{abstract}
Investigation of nitroblue tetrazolium(NBT) reduction of neutrophils was performed in the dog infected with Hepatozoon canis. No positive reactions were observed in the parasitized neutrophils by the resting and the stimulated NBT reduction tests. However, results of resting and stimulated NBT reduction tests apparently made no differences between non-parasitized neutrophils of the infected dogs and neutrophils of the non-infected dogs. These findings show that the parasitized neutrophil has no oxidative bactericidal capacity and the infected dogs had no-change in the host protective mechanism.-KEY WORDS : dog, Hepatozoon canis, neutrophil, nitroblue tetrazolium reduction test
\end{abstract}

\section{Hepatozoon canis 感染犬における好中球の Nitroblue Tetrazolium 還元能の検討}

\author{
田浦保穂・中間實徳 \\ 山口大学農学部家畜外科学教室 \\ *山口大学農学部家畜内科学教室 \\ ${ }^{* *}$ 山口大学農学部家畜病理学教室
}

村田智昭・田上礼子*・井上誠**・宇塚雄 次*

Hepatozoon canis のガモントについては形態学的 な観察や奇生好中球の酵素活性の欠損に関する研究が 報告されている $[5,8,11,12]$ 。この好中球内酵素の欠 損が広範に及べば生体にとって危機的な状態をもたら す事が考えられる。しかし，生体防御機構の上で重要 な機能面についての $H$. canis 寄生好中球に関する研 究はまだない。したがって今回, 好中球の機能検査と して Nitroblue Tetrazolium (NBT) 還元試験を行 い, 寄生好中球におけるこの還元能を調べるととも
に，寄生好中球の出現率が感染犬にどのような影響を 与えるかを検討した。

供試犬として H. canis 自然感染犬15頭を用いた。 また陰性対照群としては実験犬として隔離飼育してい るH. canis 非感染犬10頭を用いた。抗凝固片として 末梢全血 $1 \mathrm{~m} \ell に$ 対してへパリン (ヘパリン注, ミド リ十字）10単位を使用した。

NBT 還元試験はPark の方法 [14] を原法にした 伊藤らの変法 [6] を基に実施した。NBT 溶液は 
Table 1. Results of nitroblue tetrazolium reduction test of the neutrophils

\begin{tabular}{lcrr}
\hline & neutrophils of $H$. canis infected dog & $\begin{array}{r}\text { neutrophils } \\
\text { of negative } \\
\text { control dog }\end{array}$ \\
\cline { 2 - 3 } & parasitized & non-parasitized & \\
\hline $\begin{array}{l}\text { RESTING TEST } \\
\text { positive rate }(\%)\end{array}$ & 0.0 & $54.3 \pm 22.3^{11}$ & $47.5 \pm 20.0$ \\
$\quad$ score & 0.0 & $200.1 \pm 122.4$ & $187.4 \pm 149.0$ \\
$\begin{array}{l}\text { STIMULATED TEST } \\
\text { positive rate }(\%)\end{array}$ & 0.0 & & \\
$\quad$ score & 0.0 & $46.3 \pm 8.8$ & $73.9 \pm 6.7$ \\
\hline
\end{tabular}

1) : mean \pm S.D.

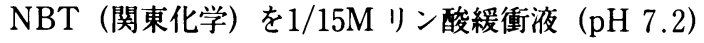
で $2 \mathrm{mg} / \mathrm{m} \ell$ の濃度に調整し, stimulated NBT 還元 試験（ $\mathrm{S}$ 試験）には Escherichia coli 由来のエンドト キシン（LPS 0127 B8, Sigma）を生理食塩水溶液で $100 \mu \mathrm{g} / \mathrm{m} \ell$ の濃度に調整した。 resting NBT 還元試 験（R試験）は次の方法で行った。 $37^{\circ} \mathrm{C} て ゙ 3$ 分間予備 加温したプラスチック試験管を用い, $25 \mu \ell$ のBT 溶液に等量の生理食塩水溶液を加えたものによくかく はんした血液を $50 \mu \ell$ 加之混合した後, $37^{\circ} \mathrm{C} て ゙ 15$ 分間 そして室温で15分間反応させた。反応終了後, 試験管 内容をよく混合して塗抹標本を作製し，ライト染色を 行った。 $\mathrm{S}$ 試験では $\mathrm{R}$ 試験の生理食塩水溶液の代わり にエンドトキシン溶液を用い， $\mathrm{R}$ 試験と同様の方法で 行つた。

成績は好中球細胞質内のフォルマザン形成を観察 し，朝長の方法 [16] を参考にガモント寄生好中球な らびに100個の非寄生好中球に対する細胞質内にフォ ルマザン沈着を呈した陽性細胞を分類し，そして0 型 a \%, I 型 b \%, II 型 c \%, III型 d \%, IV型e \%とし た時，陽性率 $=100-\mathrm{a} \% ， ス コ ア=b+4 \mathrm{c}+9 \mathrm{~d}+16 \mathrm{e}$ とした。

また，ガモント寄生率は常法により作製した末梢血 液塗抹標本をギムザ染色し, 白血球 2,000 個における ガモント寄生白血球数をカウントし，算出した。白血 球数は自動血球計数装置 (CC-110, Sysmex, Tokyo）により測定した。

検定にはStudent- $\mathrm{t}$ 検定を用い，危険染5\%以下を 有意差があるとした。

15頭の H. canis 感染犬から計101個のガモント寄 生好中球を検査したが， R 試験および $\mathrm{S}$ 試験において 陽性化したものはまったく認められなかった。

また，H. canis 感染犬における非寄生好中球の $\mathrm{R}$

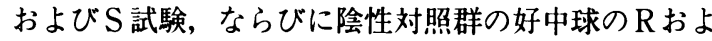
び S 試験の成績は表の通りであった（Table 1)。Rお よび S 試験における陽性率およびスコアとも $H$. canis 感染犬の非寄生好中球と㓌性対照群の好中球と の間には有意差は認められなかった。

$H$. canis 感染犬の白血球数は $13,500 \pm 3,700 / \mu \ell$,

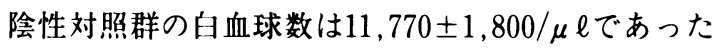
が，有意差は認められなかった。

H. canis のガモント寄生率は平均 $1.4 \%(0.1-$ 12.4\%)であった。

H. canis のガモントが寄生する犬の好中球にはパ 一オキシダーゼ，エステラーゼやフォスファターゼが 欠損している事が報告されている $[5,8,12]$ 。これら の事から $H$. canis 感染犬においては生体防御の上で 重要な位置を占める好中球の機能障害が推察される。 本研究によりガモント寄生好中球は NBT 還元能が全 く消失している事が認められた。つまりガモント寄生 好中球は好中球の本来持っている機能を失っているも のと考えられた。ガモント寄生好中球は， H. canis のガモントの寄生により殺菌能を消失した状態で血流 中に存在していると考えられた。機能消失の機序とし ては，我々は好中球の成熟段階での寄生により醳素の 蓄積ができなかったのではないかと考えており [12]，よって同様に寄生が成熟段階のため酸化的殺 菌能もほとんど発現しないのでなないかと思われる。 この点に関しては今後の検討課題であろう。

本研究から宿主側からみるとガモント奇生好中球数 が増加する事，つまり多数の感染や何等かのトリガー によってシゾゴニーの活性化等が起これば宿主にとっ て生体防御機構の一つである好中球の殺菌能の低下を 起こし，危機的な状態になってしまう事が推察され た。 
一般には，異物であるガモント寄生により好中球か ら活性化因子の誘導等を引き起こす事が考えられる。 本研究においても陰性対照群と比較して, H. canis 感染犬の非寄生好中球の NBT 還元試験の多くの項目 の成績が高くなった事や白血球数が多くなった事は, わずかながらでも寄生好中球における白血球活性化因 子の産生やコロニ一刺激因子産生が誘導されている事 によるものかも知れない。

本研究においては，ガモント寄生率の最も高い個体 でも全白血球数の $12.4 \%$ であった。この個体では臨床 的には何ら異常を認めず, 非感染好中球の NBT 還元 試験成績における陽性率並びにスコアおよび白血球数 は陰性対照群の平均值とほほ同じであった。この成績 が有意差を認めなかったのは活性化機構を誘導できな かったのか，あるいは逆に抑制する機構を誘導してい るのかも知れない。

H. canis 感染症において, ガモントの好中球寄生 率が臨床症状発現に何等かの示唆を与えるものかどう かは，本研究では明らかにできなかったが，この感染 症に関してもっと多くの症例を集めて検討する事は非 常に重要であろう。

H. canis 感染症は世界中に広がる原虫性疾患の一 つである $[1-4,7,9,13,15]$ 。日常の臨床ではH. canis 感染犬と遭遇する機会は極めて少ないが, 最近我々が わが国において行った感染調査では約 $7.9 \% の$ 感染率 であった $[10]$ 。そのほとんどの症例においてガモン 卜寄生好中球数は本研究と同じくらいの低い出現率で あった。実験用として隔離飼育されている犬にはまず 寄生しているとは考えにくいが，非常に低い寄生率の ため見逃され易いという事をここで強調しておきた い。

\section{要 約}

Hepatozoon canis 自然感染犬における好中球の
NBT 還元試験を行った。ガモント寄生好中球は resting および stimulated NBT 還元試験とも全く陽性化 を認めなかった。H. canis 感染犬のガモント非寄生 好中球の resting および stimulated NBT 還元試験に おける陽性率並びにスコアは非感染対照群と比較して 有意差を認めなかった。以上の成績からガモント寄生 好中球は酸化的殺菌能を消失していたが, 感染犬の防 御機能にはほほ異常がない事が示された。

\section{文献}

[1] Bentley, C. A. (1905). Br. Med. J., 6, 988.

[2] Carlos, E. T., Atienza, L. M., and Cabiles, C. C. (1971). Philipp. J. Vet. Med., 10, 181-189.

[3] Craig, T. M., Smallwood, J. E., Knauer, K. W., and McGrath, J. P. (1978). J. Am. Vet. Med. Assoc., 173, 967-972.

[4] Elias, E. and Homans, P. A. (1988). J. small Anim. Pract., 29, 55-62.

[5] Ibrahim, N. D. G., Rahamathulla, P. M., and Njoku, C. O. (1989). Int. J. Parasitol., 19, 915-918.

［6］伊藤值之・伊藤さや子(1991)。 日獸会誌，44，1034-1036.

[7] McCully, R. M., Basson, P. A., Bigalke, R. D., Vos, V. D., and Young, E. (1975). Onderstepoort J. Vet. Res., 42, 117-134.

[8] Mercer, S. H. and Craig, T. M. (1988). Vet. Clin. Pathol., 17, 63-65.

[9] Murata, T., Shiramizu, K., Hara, Y., Inoue, M., Shimoda, K., and Nakama, S. (1991). J. Vet. Med. Sci., 53, 1097-1099.

［10］村开智昭・網本昭輝・白水完治・原 行雄・井上，誠・鹿 江雅光·宇塚雄次·田浦保穂・中間實徳(1993). 日獣会誌, 46, 395-397.

[11] Murata, T., Inoue, M., Kanoe, M., Horio, M., Shimada, M., Yokoyama, M., Taura, Y., and Nakama, S. (1993). Jpn. J. Trop. Med. Hyg., 21, 107110 .

[12] Murata, T., Inoue, M., Kanoe, M., Kono, Y., Horio, M., Shimada, M., Yokoyama, M., Taura, Y., and Nakama, S. J. Vet. Med. Sci., (in press).

[13] Ogunkoya, A. B., Adeyanyu, J. B., and Aliu, Y. O. (1981). J . small Anim. Pract., 22, 775-777.

[14] Park, B. H., Fikrig, S. M., and Smithwick, E. M. (1968). Lancet, 2, 532-534.

[15] Rajamanickam, C., Wiesenhutter, E., and Hamid, J. (1984/85). Vet. Parasitol., 17, 151-157.

[16] 朝長万左男 (1976)。臨床血液, 17, 1266-1275. 